WSRC-RP-92-1259

\title{
ALTERNATIVE WASHING STRATEGY DURING IN-TANK PRECIPITATION PROCESSING (U)
}

WSRC-RP--92-1259

by D. D. Walker

DE93 008505

Westinghouse Savannah River Company

Savannah River Site

Aiken, South Carolina 29808

Other Authors:

D. T. Hobbs

(WSRC)

This paper was prepared in connection with work done under Contraci No. DE-AC09-89SR18035 with the U. S. Department of Energy. By acceptance of this paper, the publisher and/or recipient acknowledges the U.S.

Government's right to retain a nonexclusive, royalty-free license in and to any copyright covering this paper, along with the right $\Delta$ reproduce and to authorize others to reproduce all or part of the copyrighted paper. 


\section{DISCLAIMER}

This report was prepared as an account of work sponsored by an agency of the United States Government. Neither the United States Government nor any agency thereof, nor any of their employees, makes any warranty, express or implied, or assumes any legal liability or responsibility for the accuaracy, completeness, or usefulness of any information, apparatus, product, or prociss disclosed, or represents that its use would not infringe privately owned rights. Reference herein to any specific commercial product, process, or service by trade name, trademark, manufacturer, or otherwise does not necessarily constitute or imply its endorsement, recommendation, or favoring by the United States Government or any agency thereof. The views and opinions of authors expressed herein do not necessarily state or reflect those of the United States Government or any agency thereof.

This report has been reproduced directly from the best available copy.

Available to DOE and DOE contractors from the Office of Scientific and Technical Information, P. O. Box 62, Oak Ridge, TN 37831; prices available from (615) 576-8401.

Available to the public from the National Technical Information Service, U. S. Department of Commerce, 5285 Port Royal Rd., Springfield, VA 22161. 


\author{
Keywords: In-tank process, \\ corrosion, nydroxide, late \\ washing \\ Retention time: permanent \\ CC: W.L.Tamosaitis, 773-A \\ E.W.Holtzscheiter, 773-A \\ M. D. Boersma, 704-T \\ I. F. Landon, 704-T \\ C. T. Randal1, 704-T \\ A. S. Choi, 704-1T \\ W. B. Vanpelt, 241-152H \\ D. F. Brown, 703-H \\ J. E. Marra, 773-A \\ P. E. Zapp, 773-A \\ SRTC Records (4)
}

October 30,1992

TO: D. I. FISE, 773-A

FROM: D. D. PARER, 773-A, and D. T. BOBBS, 773-A

\section{ALTFRNATIVE MASATNG STRATHGY DURING IN-TANK PRTCIPITATION PROCESSTNG (U)}

\section{Sumary}

If late washing of precipitate is available, it is possible to modify the normal washing phase of the ITP process so that tank corrosion is prevented by inhibiting with sodium hydroxide rather than sodium nitrite. Hydroxide inhibition has numerous advantages to a hydroxide/nitrite flowsheet. 1 However, the rate of hydroxide depletion due to radiolysis and $\mathrm{CO}_{2}$ absorption were uncertainties. Based on recent experiments and calculations:

- hydroxide consumption by radiolysis will be 0.01 molar per month during Tank 49 storage,

- hydroxide depletion due to $\mathrm{CO}_{2}$ absorption will vary from 0.0006 to 0.025 molar per month for waste volumes between 50,000 and 1 million gallons and air flowrates between 100 and $200 \mathrm{cfm}$. A nominal rate of $0.006 \mathrm{molar} / \mathrm{month}$ (or less) is expected in Tank 49 after the first two ITP cycles have been completed.

A material balance for the ITP process based on hydroxide inhibition has been calculated and the potential savings have been estimated.

\section{Introduction}

Hydroxide ion in the washed precipitate slurry is consumed by two 
mechanisms during sterage: (1) radiolysis, and (2) adsorption of atmospheric carbon dioxide. The precipitate undergoes radiolyti? decomposition during storage, producing acidic products. The initial decomposition products and their relative production rates in alkaline solution are given by the following equation (per mole of KTPB that decomposes) 2 :

Moles: $\begin{gathered}\mathrm{KBPh}_{4}+\mathrm{H}_{2} \mathrm{O} \\ \text { potassium } \\ \text { petraphenylborate }\end{gathered}$
te.6

\begin{tabular}{|c|c|c|c|c|}
\hline $\mathrm{Ph}-\mathrm{O}^{-}$ & + & $\mathrm{Ph}-\mathrm{B}(\mathrm{O}) 2^{2-}$ & $+\mathrm{B}(\mathrm{OH}) 2_{2} \mathrm{O}^{-}$ & + \\
\hline $\begin{array}{c}0.94 \\
\text { phenol }\end{array}$ & & $\begin{array}{c}0.53 \\
\text { phenylboric } \\
\text { acld }\end{array}$ & $\begin{array}{r}0.47 \\
\text { boric } \\
\text { acid }\end{array}$ & \\
\hline
\end{tabular}

Radiolysis will consume about 7.58 of the precipitate per year by this reaction, corresponding to a hydroxide consumption rate of 0.003 molar/month. The inttlal decomposition products can also be broken down in reactions which consume more hydroxide ion and eventually produce carbonate.

All of the SRS waste tanks are equipped with active ventilation systems to prevent the buildup of flammable vapor mixtures. Hydroxide is depleted during the storage of alkaline waste solutions due to the absorption and reaction of carbon dioxide present in the air which passes through the waste tank. The rate of absorption of carbon dioxide has been previously measured for a variety of waste tanks including Tank 48 which contained the washed precipitate slurry from the 1983 In-Tank Demonstration. 3

The most recent results from corrosion testing indicate that a minimum free hydroxide concentration of 1.5 molar is required to prevent corrosion in the ITP process up to $60^{\circ} \mathrm{C} .4^{4}$ Further corrosion testing could change this. The material balance given below assumes that a $20 \%$ excess of NaOH will be used as a safety margin above the required amount.

\section{Rate of OH- Depletion by Radiolysis}

The rate of hydroxide depletion was measured on simulated slurries irradiated in a Co-60 source. The compositions of the simulated slurries (Table I) were similar to those expected in the ITP process with late washing. Specifically, the composition of the liquid phase was adjusted to reflect the high hydroxide concentration expected if $\mathrm{NaOH}$ is used as the only corrosion inhibitor. The slurries were irradiated in closed containers to doses of up to 320 megarads, simulating over two years of tank farm storage (Note: slurry containing $36 \mathrm{Ci}$ of $\mathrm{Cs}-137$ per galion receives a dose of 145 megarads per year).

The changes in the free hydroxide concentration are shown in Figure 1 and the calculated rates are listed in Table II. In both slurries, there was a sligit increase in free hydroxide during the first 50 Mrads of radiation dose. This was followed by a decline 
TABLE I. Initial Composition of Simulated KTPB Slurries for Radiolysis Experiments

cemponent

$\mathrm{Na}^{+}$

$\mathrm{OH}^{-}$

$\mathrm{NO}_{3}^{-}$

$\mathrm{NO}_{2}^{-}$

$\mathrm{SO}_{4} 2-$

$\mathrm{CO}_{3}{ }^{2-}$

KTPB
Concentration in Liquid (molar) LOW OH $\mathrm{High} \mathrm{OH}$

1.3

2.1

1.1

1.9

0.09

0.08

0.04

0.03

0.01

0.009

0.01

10 wt 8

0.008

10 wt 8

TABLE II. Rates of Hydroxide Depletion and Carbonate Accumulation

\begin{tabular}{ccc}
$\begin{array}{c}\text { Initial } \\
\text { Free OH- } \\
\text { (M) }\end{array}$ & $\begin{array}{c}\text { Loss of } \\
\text { Free OH- } \\
\text { (M/month) }\end{array}$ & $\begin{array}{c}\text { Accumulation of } \\
\text { Carbonate } \\
\text { (M/month) }\end{array}$ \\
\cline { 2 - 3 } 1.1 & 0.0115 & 0.0051 \\
1.9 & 0.0128 & 0.0055
\end{tabular}

in the free hydroxide which was linear with dose. The rates of hydroxide depletion (after the initial increase) were similar for the two slurries. The average rate determined from these two experiments is $1.0 \times 10^{-3} \mathrm{molar} / \mathrm{Mrad}$ or $0.012 \pm .001 \mathrm{molar} / \mathrm{month}$ (for a slurry with $36 \mathrm{Ci}$ of $\mathrm{Cs}-137 / \mathrm{gal})$. This is similar to the previously reported rate of 0.01 molar/month at much lower hydroxide, nitrate, and nitrite concentrations. 2 There is a trend in the data from the three experiments which suggests that there may be a slight dependence in the rate of depletion on the initial free hydroxide concentration. This trend is not expected and is so small that it is likely due to experimental errors.

The rates of carbonate accumulation (Figure 2 and Tarle II) were very similar for the two slurries, although again the rate at the higher hydroxide concentration is slightly larger. The rate of carbonate accumulation for both slurries is slightly less than half of the rate of free hydroxide depletion as expected. Each mole of carbon dioxide formed will consume two moles of free hydroxide to form the carbonate ion. Since other hydroxide-consuming reactions are taking place at the same time, the rate of hydroxide depletion should be more than twice the carbonate accumulation rate.

\section{Rate of $\mathrm{OB}^{-}$Depletion by Carbon Dioxide Absorption}

The hydroxide depletion rate in Tank 49 due to the absorption of atmospheric carbon dioxide has been calculated as a function of waste volume and air flowrate. 5 The following bases were used to calculate the hydroxide depletion rates as a function of waste volume and air flowrate: (1) the partial pressure of carbon dioxide in the air entering the tank is a constant $360 \mathrm{ppm}$ (this is the 


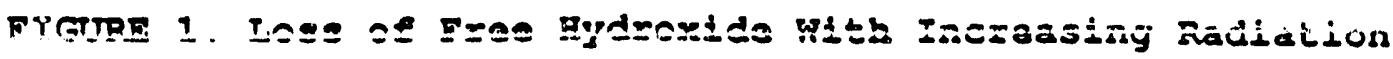
Dose

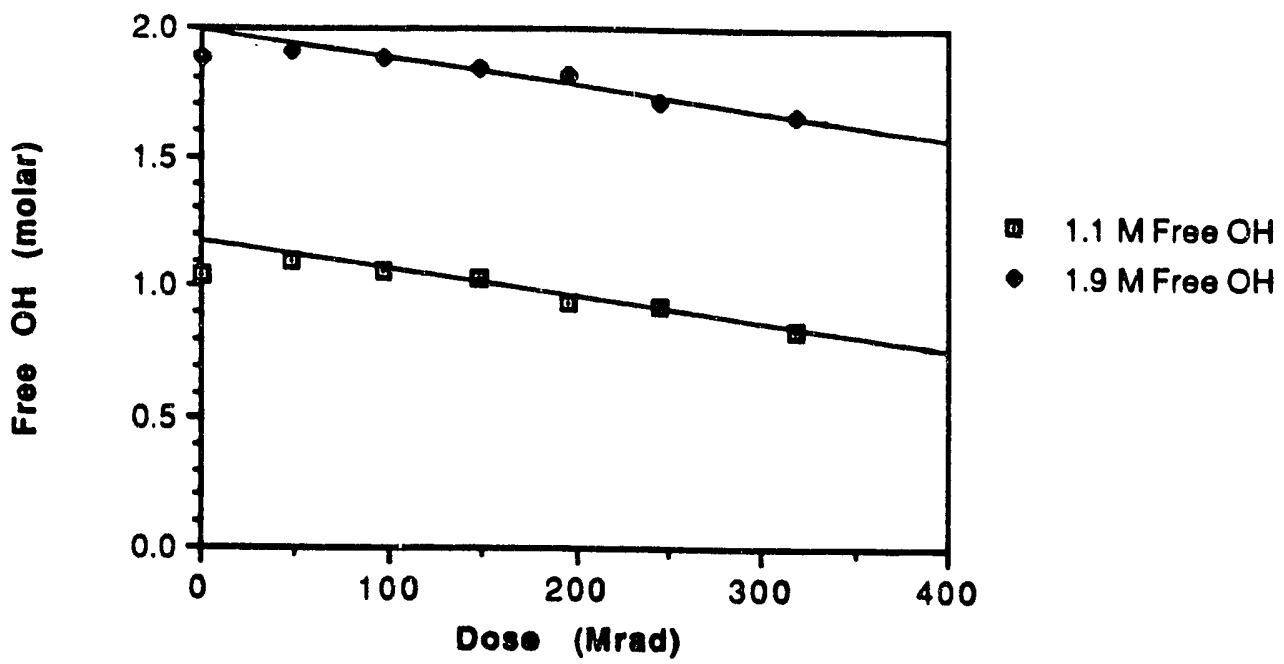

FIGURE 2. Accumulation of Carbonate with Incressing Radiation Dose

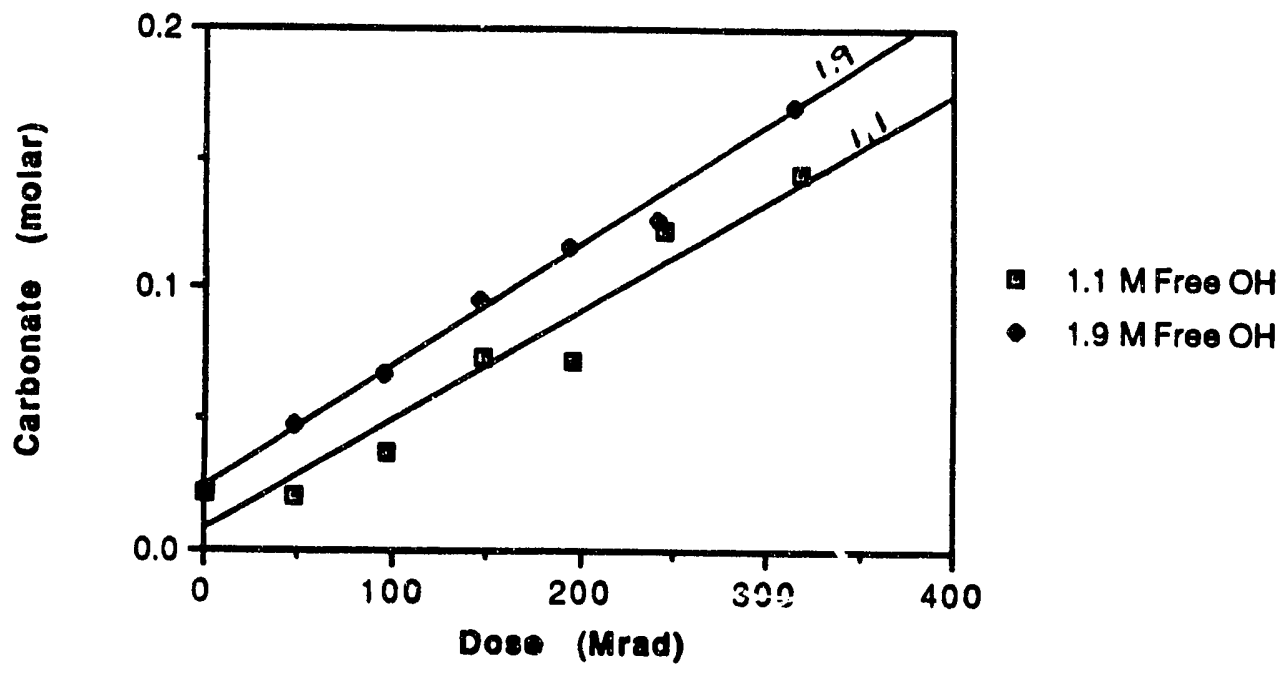


average of several measurements made in the SRS Tank Earm over a one year perlod), (2) the air temperature is a constant $50^{\circ} \mathrm{r}$. (anticipated high temperature for waste in Tank 49), (3) the fraction of carbon dioxide absorbed by the precipitate slurry is independent of the slurrry volume and the ventilation flowrate and has a value of $0.717,(4)$ one mole of carbon dioxide consumes two moles of hydroxide, (5) the volume of precipitate slurry ranges from 50,000 to $1,000,000$ gallons, and (6) perfect mixing of air and nitrogen in the ventilation system with an air flowrate of between 100 and $200 \mathrm{cfm}$ (total ventilation flowrate is higher due to the nitrogen purge gas). The calculated depletion rates are given in Table III. A graph of the depletion rate versus the volume of waste for three air flowrates $(100,150$, and $200 \mathrm{cfm})$ is shown in Figure 3. The rate of absorption of carbon dioxide is constant for a given flowrate. However, because the volume of waste will be changing on a regular basis, the depletion rate on a unit volume basis will change. The rate increases if the volume of waste decreases. The depletion rate also increases with an increase in the purge air flowrate. This is a result of an increase in the carbon dioxide entering the tank and being absorbed into solution and reacting with hydroxide to form carbonate.

The expected ventilation rate in ITP is $500 \mathrm{cfm}$ total flow, with $125 \mathrm{cfm}$ of air inleakage and $375 \mathrm{cfm}$ of nitrogen purge. After two cycles of ITP processing there should be at least 250,000 gallons of precipitate slurry in Tank 49. Under these conditions, the hydroxide consumption rate will be about 0.00013 molar/day or 0.004 molar per month.

\section{Figure 3. Effect of Air Flowrate and Waste Volume on the Rate of Hydroxide Deplation Due to Carbon Dioxide Absorption}

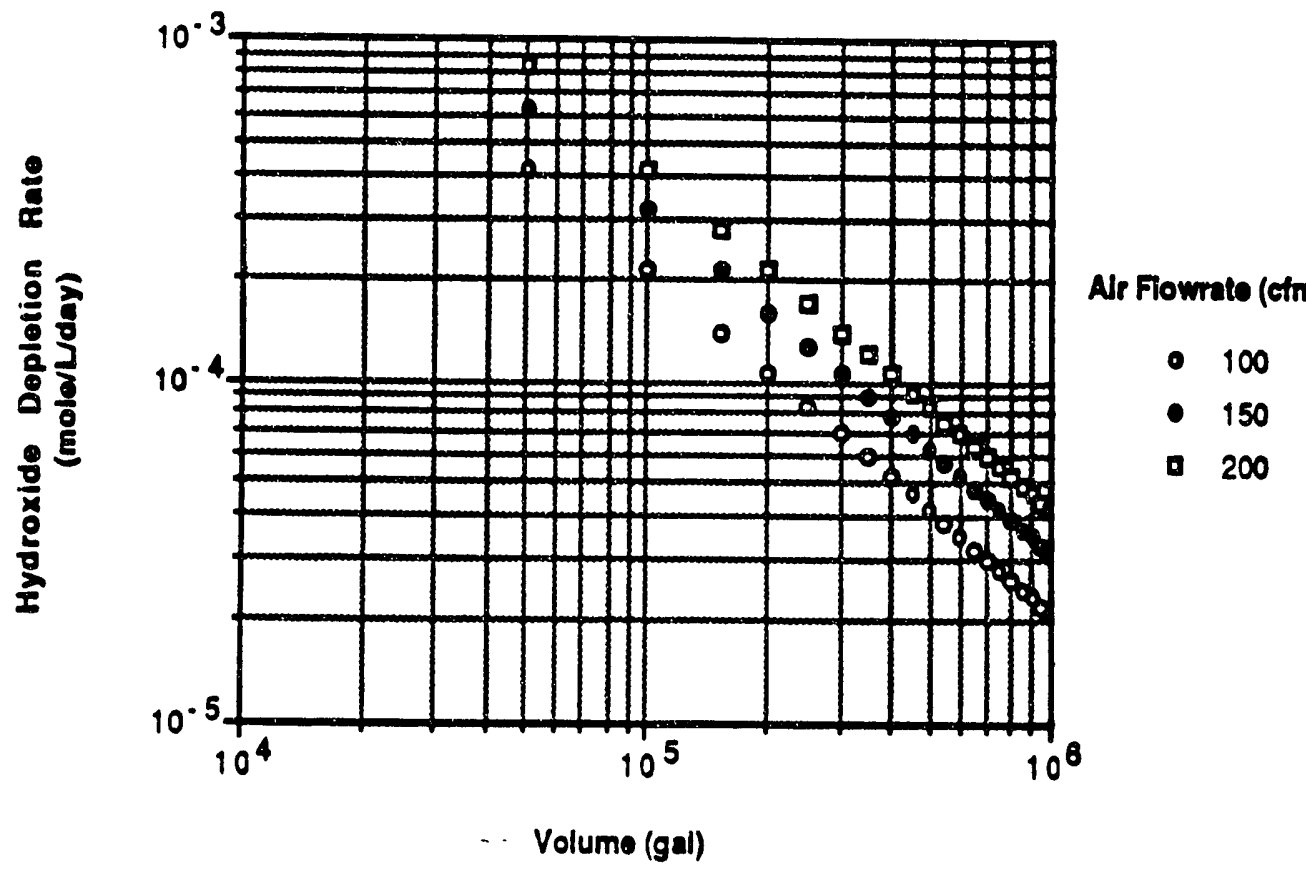


TABIE III. Tank 49 Hydroxide Depletion Rates

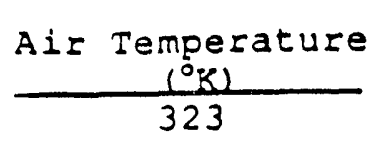

Air Elowrate (cfm)

mole $\mathrm{CO2}$ absorbed/day

mole OH depleted/day

Tank velume (gal)

50000
100000
150000
200000
250000
300000
350000
400000
450000
500000
550000
600000
650000
700000
750000
800000
850000
900000
950000
1000000
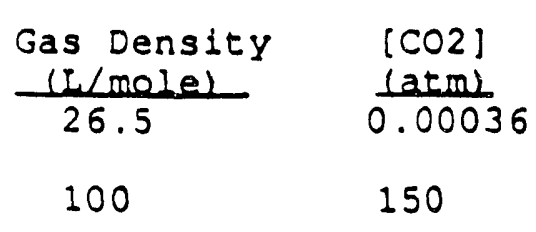

$3.97 \mathrm{E}+01$

150

Absorption
Eraction
0.717

$7.94 E+01$

$5.96 E+01$

200

Bydroxide Dopletion Rate (mole/L/day)

100 afm

\begin{abstract}
4.20E-04
\end{abstract}
$2.10 E-04$

1. $40 E-04$

1. $05 E-04$

8. 39E-05

$7.00 E-05$

$6.00 E-05$

$5.25 E-05$

4. 66E-05

4. 20E-05

3. $82 \mathrm{E}-05$

3. $50 \varepsilon-05$

3. $23 E-05$

3. $00 \mathrm{E}-05$

2. $80 E-05$

2. $62 E-05$

2. $47 E-05$

$2.33 E-05$

2. 21E-05

2.10E-05
150 afm

6. 30E-04

3. 15E-04

$2.10 E-04$

1. $57 \mathrm{E}-04$

$1.26 \mathrm{E}-04$

$1.05 E-04$

8. $99 \varepsilon-05$

$7.87 \mathrm{E}-05$

$7.00 \mathrm{E}-05$

$6.30 E-05$

$5.72 E-05$

$5.25 E-05$

4. 84E-05

4. 50E-05

4. 20E-05

3. $94 E-05$

3. $70 E-05$

3. 50E-05

3. 31E-05

3. $15 E-05$

\section{0 afm}

8. 39E-04

4. 20E-04

2. $80 E-04$

2. 10E-04

1. $68 \varepsilon-04$

1. $40 E-04$

$1.20 E-04$

$1.05 \mathrm{E}-04$

9.33E-05

8. 35E-05

$7.63 \mathrm{E}-05$

$7.00 \mathrm{E}-05$

$6.46 \mathrm{E}-05$

$6.00 E-05$

5. 60E-05

5. 25E-05

4. $94 E-05$

4. $66 \mathrm{E}-05$

4. 42E-05

4. 20E-05 


\section{Material Balance for the Bydroxide Flowsheet}

In previous material balances for the ITP process, a combination of sodium hydroxide and sodium nitrite has always been used to meet corrosion inhibitor requirements for Tank 48 and Tank 49.6

However, if the Late Wash Facility is constructed, a new approach to corrosion prevention in which only sodium hydroxide is used becomes feasible. Recent corrosion test results indicate that 1.5 molar free hydroxide is sufficient to prevent corrosion at low nitrate and nitrite levels for temperatures up to $70^{\circ} \mathrm{C} .4$ Thus, the new approach is based on maintaining a minimum of 1.8 molar hydroxide in Tanks 49 and 49 throughout the process cycle. The $20 \%$ excess over the requirement is a safety margin to avoid violations of Operational Safety Requirements. Washing in Tank 48 is reduced by almost half so the precipitate is stored in a "partially washed" condition. Washing is completed by the Late washing process. Compared to the material balance using nitrite as the inhibitor (Late Wash flowsheet at $60^{\circ} \mathrm{C}$ ), $6 \mathrm{C}$ the hydroxide flowsheet has the following advantages:

- Volume of liquid to Saltstone is reduced by 1 million gallons per year $(-12 \%)$,

- NaTPB requirements are reduced by $33,000 \mathrm{gal} / \mathrm{yr}(-10 \%)$,

- $50 \% \mathrm{NaOH}$ requirements are increased by $17,000 \mathrm{gal} / \mathrm{yr}(+12 \%)$ (this is the total for $T k 48$, Tk 49, Tk 22, and Late Washing)

- Sodium nitrite requirements are reduced by $48,000 \mathrm{gal} / \mathrm{yr}$ $(-100 \%)$,

- ITP cycle time is reduced by 14 days $(-11 \%)$.

This material balance is based on the same assumptions that were used in the nitrite flowsheet. $6 \mathrm{c}$ Late washing is assumed to reprecipitate $\mathrm{Cs}$ and $\mathrm{K}$ before washing. A 15 -fold reduction in soluble salts is required in late washing, which is slightly less than in the nitrite flowsheet (16-fold reduction). The spent late washwater is inhibited to $1.2 \mathrm{M} \mathrm{NaOH}$ before it is transferred to Tank 22 (same as nitrite flowsheet). The maximum tank temperatures were assumed to be $55^{\circ} \mathrm{C}$ in Tank 48 although the inhibitor requirements for $70^{\circ} \mathrm{C}$ are met. Both material balances are based on average salt composition and on emptying one salt tank per year (three ITP cycles per year; nine ITP batches pex year).

The washing endpoint in Tank 48 is based on several considerations. These include:

1. rate of radiolytic conversion of nitrate into nitrite (assumed to be complete within two years) ${ }^{7}$

2 . rate of radiolytic destruction of nitrite ( $G=0.3$ molecules/100 ev, $36 \mathrm{Ci}$ of $\mathrm{Cs}-137 / \mathrm{gal}, 2$ years of storage) 7

3. feed speclfication for nitrite $(<0,18$ molar $)$ to Late Washing and to DWPF $(<0.01$ molar $) .8$

4. rate of consumption of free hydroxide in Tank 49 ( 0.016 molar/month, $36 \mathrm{Cl}$ of $\mathrm{Cs}-137 / \mathrm{gal}, 2$ years storage) 
When radiolytic conversion of nitrate to nitrite, destruction of nitrite, and batch additions to Tank 49 are considered, the net resuit must be a nitrite concentration that does not exceed the washing capabilities of Late washing. To accomplish this, Tank 48 washing must reduce the sum of the nitrate and nitrite concentrations to less than 0.25 molar.

The free hydroxide concentration must be maintained above 1.8 molar for corrosion inhibition in Tank 48 and Tank 49. A complication in Tank 49 is the depletion of free hydroxide by radiolysis and absorption of carbon dioxide from the ventilation air. To avoid having to add hydroxide inhibitor to Tank 49 , enough excess $\mathrm{NaOH}$ is left in the washed preclpitate in Tank 48 so that hydroxide depletion during two years of storage is accommodated. The hydroxide depletion rate is assumed to be $0.16 \mathrm{molar} / \mathrm{month}$, or 0.38 molar during two years of storage. Thus, the last $\mathrm{NaOH}$ addition to Tank 48 during washing is sized so that the free hydroxide concentration is 2.18 molar at the end of washing.

A process flow diagram for the ITP process with Late washing is shown in Eigure 4. It is similar to previous material balances $6 \mathrm{c}$ except that no sodium nitrite is added to Tank 48 . The batch volumes for a cycle are shown in Table IV. The concentrations of the major components in these solutions are listed in Table $V$. The composition of the washed precipitate at various stages in Tank 49 and Late Washing is shown in Table VI. Table VII shows the sequence of inhibitor ajditions and the composition of the washed precipitate during Tank 48 washing. Table VIII lists the process steps and timing.

\section{Quality Assurance}

The new data and calculations reported for hydroxide depletion, carbonate accumulation, and material balance are recorded in Laboratory Notebook \#WSRC-RP-92-132, pp 132-148. Calculations of the absorption of carbon dioxide are recorded in laboratory notebook \#WSRC-NB-91-151, pp 156-159. Sodium tetraphenylborate used in the preparation of slurries was obtained from AFF, Inc. and was not purified before use. All other chemicals used to make slurries were prepared from reagent grade chemicals. Analyses for free hydroxide and carbonate were performed by the SRTC Analytical Development section as routine samples. This work was carried out in accordance with the following program plan: D. D. Walker, "Late Washing Program Plan (U)," SRT-IWP-92-092, Rev.1, June 15, 1992.

\section{References}

1. L. F. Landon, "Alternative Washing Strategy During In-Tank Precipitation Processes," SRTC-PTD-92-35, July 27, 1992.

2. D. D. Walker, "Benzene Distribution in Product Streams from In-Tank Processing," DPST-86-390, January 15, 1987.

3. D. T. Hobbs, "Hydroxide Depletion Rate in Tank 49 Due to the Absorption of Atmospheric Carbon Dioxide," SRT-LWP-92-107, July 28, 1992 .

4. P. E. Zapp, personal communication, October 1992. 
5. D. T. Hobbs, "Absorption of Carhon ninxite in Traste Tarl:o," DPST-87-5af; Sentemher 3, 198?.

6.a. D.D.Walker and B.A. Hamm, "Material Balance and Flanned Operating Schedule for the In-Tank Process (U)," WSRC-RP-89-1303, December 27, 1989.

b. D. D. Walker, "Material Balance for the In-Tank Precipitation Process with Late Washing (U)," WSRC-RP-92-396, April 16, 1992.

C. D. D. Walker, "Material Balance for the ITP Process with Late Washing," SRT-LWP-92-074, July 14, 1992.

7. D. D. Walker and B. S. Johnston, "Radiolytically Induced Changes in the Concentration of Nitrate and Nitrite Ions in Potassium Tetraphenylborate Slurries," DPST-86-716, October 14, 1986.

8. R. A. Jacobs and N. D. Hutson, "DWPR/IWM Memorandum of Agreement: DWPF Feed Acceptance Criteria and Target Values (U) , " WSRC-IM-92-55, draft dated May 1992 
FIGUR: 4. Process Flow Diagram for the ITP Process

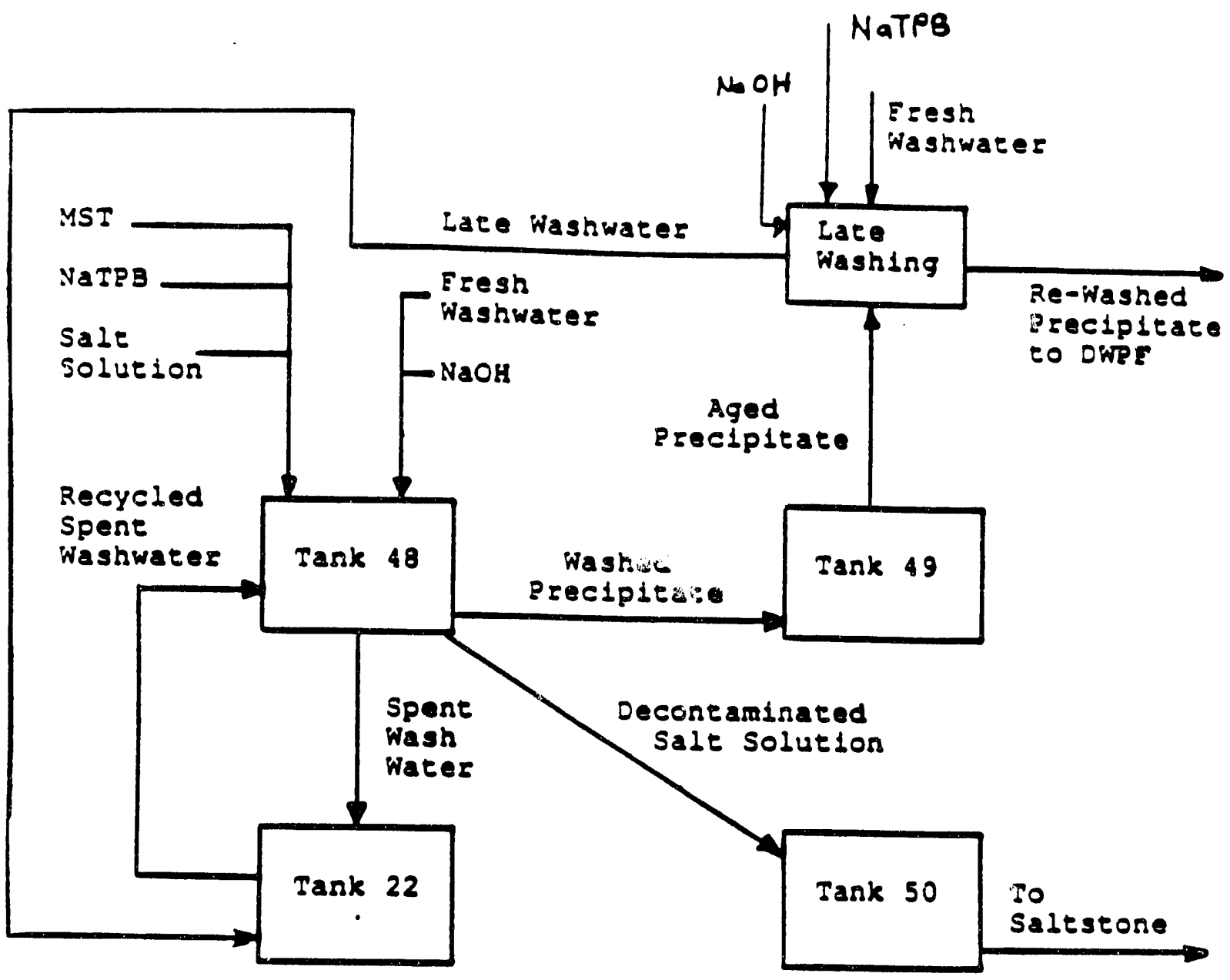


TABIE IV. Process Volumes for the Hydroxide Flowsheet

Component

Heel

Salt solution

Recycled washwater

Late washwater

STPB

MST

Flush water

Total batch volume:

10 wt of slurry:

before washing: 54.4 after washing:

Eiltrate (to Tk 50):

Filtrate total per cycle:
Volume (2gand

$\begin{array}{cc}\text { Batch \#2 } & \text { Batch \#3 } \\ 54.4 & 90.5 \\ 630 & 630 \\ 90 & 90 \\ 89 & 89 \\ 25.1 & 25.1 \\ 0 & 0 \\ \frac{1}{835} & 1 \\ -835\end{array}$

90.5

125.2

120.7

799

800

2,393

Solids (kg)

$\begin{array}{lrrr}\text { KTHB } & 16,700 & 33,700 & 50,000 \\ \text { STPB } & 8,000 & 8,000 & 8,000 \\ \text { MST } & 1,000 & 1,000 & 1,000\end{array}$

8,000

1,000

TABLE V. Stream Compositions for the Hydroxide Flowsheet

component

Salt

Sol'n

$\mathrm{Na}^{+}$

$\mathrm{OH}^{-}$

$\mathrm{NO}_{3}^{-}$

$\mathrm{NO}_{2}^{-}$

$\mathrm{TPB}^{-}$

Cs-137(Ci/L)
6.3

1.72

2.42

0.89

0.0

0.7 concentration (molar)

Recycled Iate
Washwater

Filtrate

(to ik 50)

3.84

2.06

5.44

2. 44

1.80

1.76

0.72

0.00033

1.91

0.27

0.051

0.71

0.01

0.004

0.0018

0.000005

0.0038

0.000003 
TABLE VI. Composition of Concentrated Precipitate

component

$\mathrm{KTPB}$

CSTPB

MST

$\mathrm{K}^{+}$

$\mathrm{Na}^{+}$

$\mathrm{NO}_{3}^{-}$

concentration (molar)
To Tk 49 After
2 yes $\begin{gathered}\text { After } \\ \text { Late Washing }\end{gathered}$

0.0

0.050

0.0

2. 54

2. 54

0.18

2.16

0.175

1.78

0.126

0.065

$0.03-.001$

0.15

$0.002-.0007$

0.010
1.7

9.5

11.3 soluble: solid:

11.3

concen 93.0

109.4

1.16

2.38

109.4

1.16

2.38

TABLE VII. Corrosion Inhibitor Additions During Tank 48 Washing

\begin{tabular}{|c|c|c|c|c|c|c|}
\hline \multirow{2}{*}{ Stage } & \multirow{2}{*}{$\mathrm{Nat}$} & \multicolumn{3}{|c|}{ concentration (molar) } & \multicolumn{2}{|c|}{$\begin{array}{l}\text { Volume } \\
\text { (kgal) }\end{array}$} \\
\hline & & & & & Step & Total \\
\hline Initial & 5.44 & 1.76 & 1.91 & 0.71 & 0 & 0 \\
\hline End lst filtration & 3.50 & $1.13 *$ & 1.22 & 0.46 & 50 & 50 \\
\hline Add $12,000 \mathrm{gal} \mathrm{NaOH}$ & 5.05 & 2.91 & 1.11 & 0.41 & 12 & 62 \\
\hline End 2nd filtration & 3.13 & 1.79 & 0.68 & 0.25 & 55 & 117 \\
\hline Add 12,000 gal $\mathrm{NaOH}$ & 4.71 & 3.50 & 0.61 & 0.23 & 12 & 129 \\
\hline End 3rd filtration & 2.46 & 1.80 & 0.32 & 0.12 & 75 & 204 \\
\hline Add $12,000 \mathrm{gal} \mathrm{NaOH}$ & 4.11 & 3.52 & 0.28 & 0.11 & 12 & 216 \\
\hline End 4 th filtration & 2.54 & 2.16 & 0.175 & 0.065 & 55 & 271 \\
\hline
\end{tabular}


TABIS VIII. Hydroxide Flowsheet Process Timing

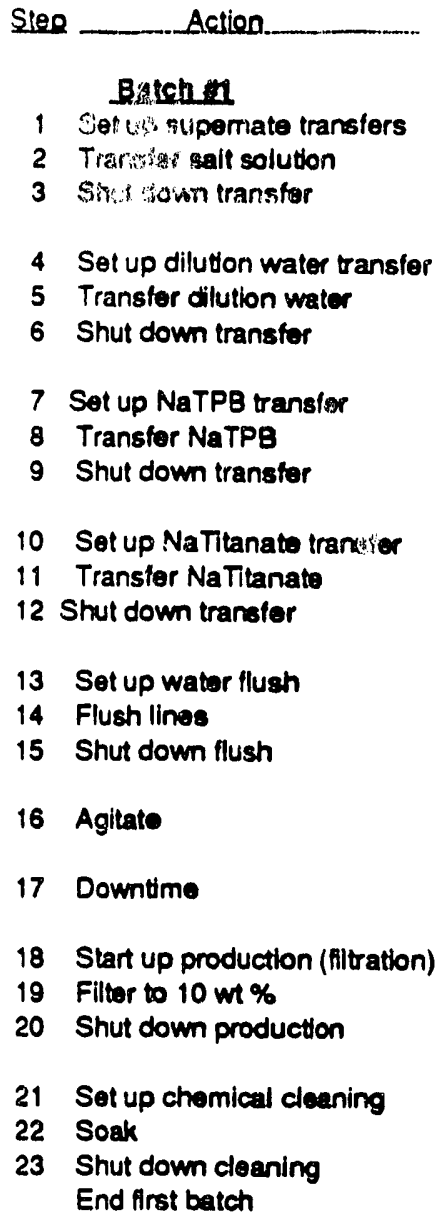

\section{Batch?}

Sol up supemate transfere

Transter salt solution

3 Shut down transtor

4 Set up dilution water transfor

5 Transfer dilution water

6 Shut down transfer

7 Sel up NaTPB tranater

8 Transfor NaTPB

9 Shut down transfer

10 Sot up water flush

11 Flush lines

12 Shut down flush

13 Agitate

14 Downtime

15 Start up proctuction (filtration)

16 Filter to 10 wt \%

17 Shut down production

18 Set up chemical cleaning

19 Soak

20 Shut down cleaning

End of second batch

\begin{tabular}{|c|c|c|c|}
\hline \multirow[t]{2}{*}{$\frac{\text { Volume }}{\text { (gal) }}$} & $\frac{\text { Bate }}{\text { (gpm) }}$ & $\frac{\operatorname{Tims}}{(h r)}$ & $\frac{\text { Suticita }}{\text { (days) }}$ \\
\hline & & 1.0 & \\
\hline \multirow[t]{3}{*}{630,000} & 75 & 140.0 & \\
\hline & & 1.0 & 5.9 \\
\hline & & 1.0 & \\
\hline \multirow[t]{3}{*}{179,000} & 100 & 29.8 & \\
\hline & & 1.0 & 1.3 \\
\hline & & 1.0 & \\
\hline \multirow[t]{3}{*}{36,300} & 100 & 6.0 & \\
\hline & & 1.0 & .3 \\
\hline & & 1.0 & \\
\hline \multirow[t]{3}{*}{2,040} & 100 & .3 & \\
\hline & & 1.0 & .1 \\
\hline & & 1.0 & \\
\hline \multirow[t]{5}{*}{1,000} & 100 & .2 & \\
\hline & & 1.0 & .1 \\
\hline & & 72.0 & 3.0 \\
\hline & & 229.9 & 9.6 \\
\hline & & 24.0 & \\
\hline \multirow[t]{5}{*}{793,900} & & 117.4 & \\
\hline & & 20.0 & 6.7 \\
\hline & & 18.0 & \\
\hline & & 24.0 & \\
\hline & & 6.0 & $\frac{2.0}{29.0}$ \\
\hline
\end{tabular}

\begin{tabular}{|c|c|c|c|}
\hline \multirow{3}{*}{630,000} & \multicolumn{3}{|c|}{1.0} \\
\hline & 75 & 140.0 & \\
\hline & & 1.0 & 5.9 \\
\hline \multirow{3}{*}{179,000} & & 1.0 & \\
\hline & 100 & 29.8 & \\
\hline & & 1.0 & 1.3 \\
\hline \multirow{3}{*}{25,000} & & 1.0 & \\
\hline & 100 & 4.2 & \\
\hline & & 1.0 & .3 \\
\hline \multirow{3}{*}{1,000} & & 1.0 & \\
\hline & 100 & .2 & \\
\hline & & 1.0 & .1 \\
\hline \multirow{8}{*}{799,000} & & 72.0 & 3.0 \\
\hline & & 229.9 & 9.6 \\
\hline & & 24.0 & \\
\hline & & 121.4 & \\
\hline & & 20.0 & 6.9 \\
\hline & & 18.0 & \\
\hline & & 24.0 & \\
\hline & & 6.0 & 20 \\
\hline
\end{tabular}


TABIE VIII. Hydroxide Flowsheet Process Timing (continued)

\section{Barch 13}

Set up supermate transfers

Transter salt solution

3 Shut down transter

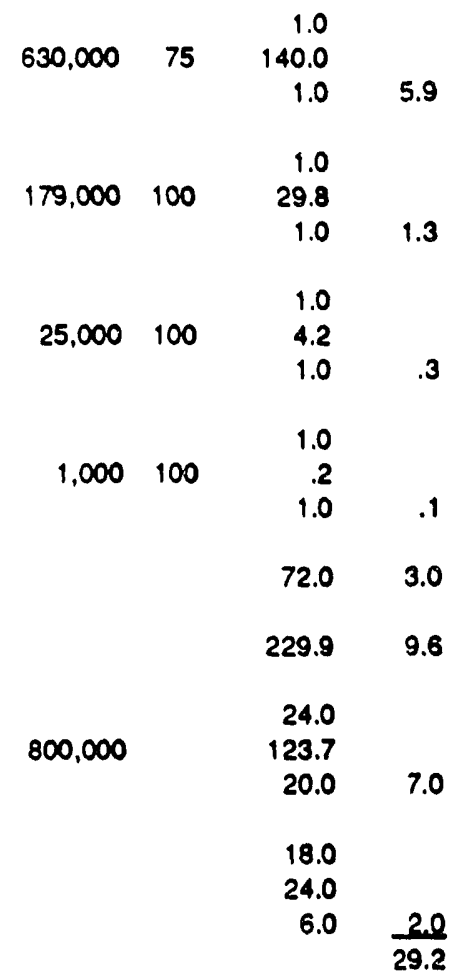

4 Set up dilution water transfer

5 Transfer dilution water

Shut down transfer

7 Set up NaTPB transfer

8 Transter NaTPB

9 Shut down transfor

10 Sot up water flush

11 Flush lines

12 Shut down flush

13 Agitate

14 Downtime

15 Start up production (filtration)

16 Filter to 10 wt \%

17 Shut down production

18 Set up chemical cleaning

19 Soak

20 Shut down cleaning

End of third batch

\section{Wrangrein}

1 Set up wash

2 Wash

3 Add NaOH Inhibitor

4 Wash

5 Add NaOH inhibitor

6 Wash

7 Add NaNO2 inhibitor

8 Wash

9 Shut down wash

$\begin{array}{rr}50,000 & 14 \\ 12,000 & 100 \\ 55,000 & 14 \\ 12,000 & 100 \\ 75,000 & 14 \\ 12,000 & 100 \\ 55,000 & 14\end{array}$

10 Sampio TK 48

11 Set up slumy transfer to Tk 49

12 Transtor

13 Shut down transfer

14 Sot up chemical cleaning

16 Shut down cleaning End of wash cycle 

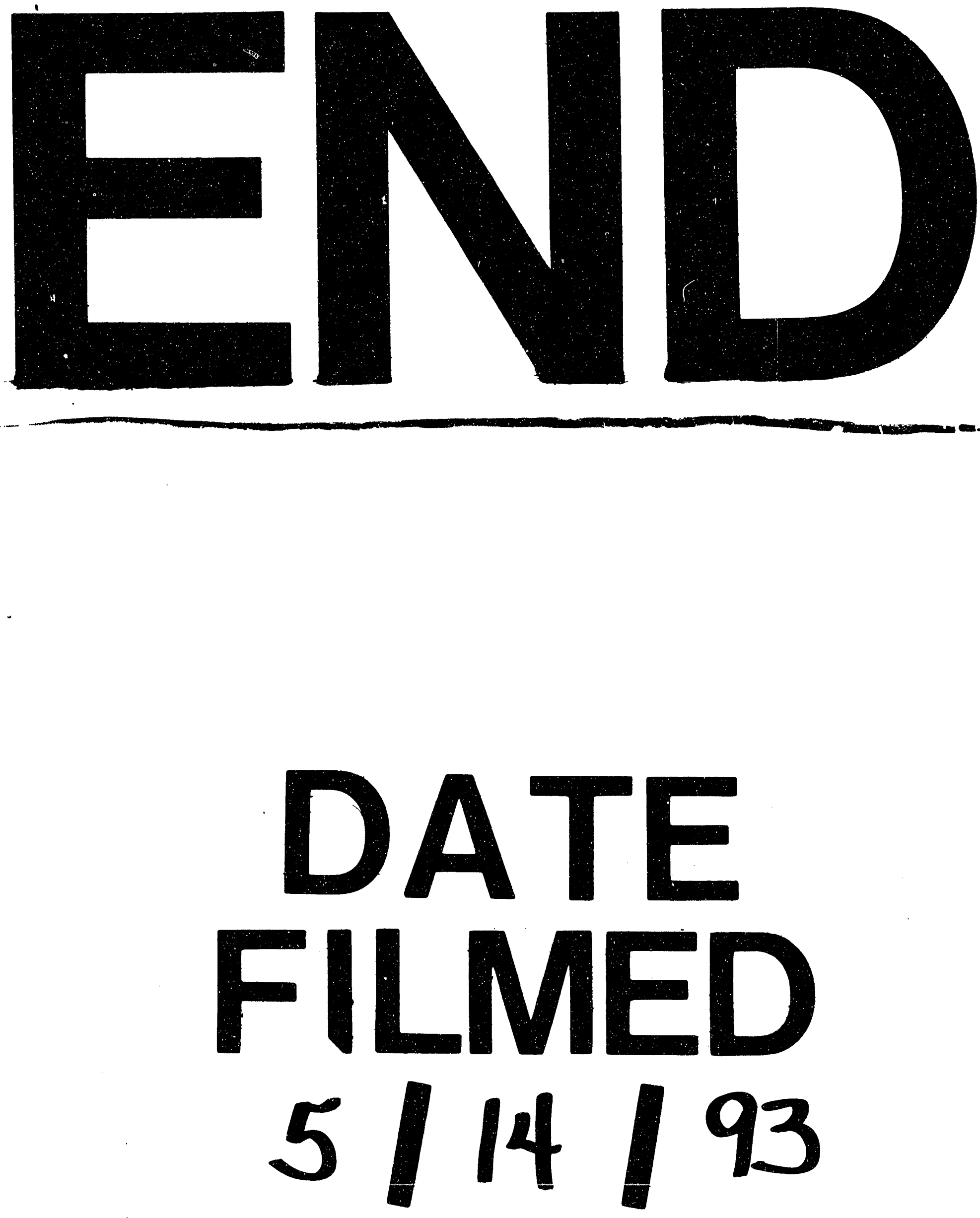
